\title{
STREET TRADE AND THE ATTAINMENT OF URBAN RESILIENCE AND ADAPTATION IN LAGOS, NIGERIA
}

\author{
Ademola Omoegon*
}

\begin{abstract}
Rapid urbanization rates and the proliferation of informal activities in vulnerable locations present significant challenges to urban resilience and adaptation, particularly in cities seeking to reduce poverty and improve economic growth. Inclusive urban governance has been identified as being vital to building resilience. Informal employment is the life blood of African cities, as evidenced by the multitude of street traders which abound in urban areas. However, in recent times many city authorities in Africa have adopted neo-liberal development policies which have led to the sanitization of public space and displacement of street traders, as well as a consequent worsening of the already precarious working conditions of traders and a significant damage of their limited associational structure, thus reducing their capacity to participate in urban governance. Through a case study of Lagos, Nigeria which possesses the largest informal economy in Africa, this paper examines the challenges which associations of the working poor face and the effect of this on urban resilience efforts. By exploring the experiences of street traders, the paper aims to investigate their current forms of organisation, their role in urban governance and how these factors can enhance or hinder urban resilience and adaptation.
\end{abstract}

Keywords: Street trade, urban resilience, informal economy, urban governance, Lagos

\section{INTRODUCTION}

The current rate of urbanisation globally is extraordinary, with UN estimates indicating that in 2008 more than half of the world's population were residing in cities and that by 2025 about 5 billion of the world's inhabitants would be residents in cities. Most recent urbanisation is taking place in the developing regions such as Africa, Asia and Latin America, largely in the absence of economic development thus, resulting in what has been referred to as an urbanisation of poverty. This urbanisation process is unlike the urbanisation in the developed world context where urbanisation occurred alongside industrial revolution and significant economic growth. Consequently many often poor urban inhabitants in the developing world reside and participate in largely unplanned and marginal informal settlements and economic activities, thereby making them highly vulnerable to both climate and non-climate-related shocks and stresses, and thus significantly limiting urban resilience efforts.

The informal economy is a major source of urban jobs for the growing urban poor in most cities in the developing world. This is particularly the case in Africa where street traders are a dominant feature of urban areas; with street trade one of the largest sub-groups in the informal economy. Nevertheless, street trader displacements are a common government policy in developing world cities, despite widespread arguments that they lead to exclusion and have harmful effects on street traders and other urban groups. Trader displacements vary in nature and scale as well as their effects on traders, trading activities, and wider society. But trader displacements are widely argued to be undertaken and conducted in favour of political and economic elites. The occurrence of trader displacements is an indication of the nature of urban governance within a particular context, as displacements are part of public management efforts by the state. Governance encompasses various practices through which the economy and society are regulated by the state and other actors (Lindell, 2008).

Trader displacement policies are generally based on preconceived notions of what urban governance and management entails. Relocation and eviction policies towards street traders and other informal economy workers are often based on normative perspectives to urban governance and planning and idealised images of the urban sphere, and in many cases such policies are based on narrowly conceived political processes and overlook the importance of the urban informal economy and widespread impacts on poverty levels (Brown et al. 2014). A key political undertone of street trader displacements and similar actions is the minimal involvement

* Dr. Ademola Omoegon, Lecturer, Department of Architecture, University of Lagos.

Email Correspondence: omoegun22@yahoo.com

Journal of Research in Architecture and Planning: Vol. 24, 2018 (First Issue) 
of affected parties in the processes that lead up to these decisions. Although recent developments have expanded the opportunities for victims of such exercises to exert greater influence, significant shortcomings still exist. In recent times opportunities for groups of underprivileged residents to participate in decision-making have been broadened, however there are indications that the impact of this remains marginal as extensive aggression towards street traders and their sustained violent evictions in the context of the growing urbanisation of poverty remain staggering (Brown et al., 2009).

Urban resilience is described as the ability of cities to function such that the residents and workers in them - especially the poor and vulnerable - survive and thrive irrespective of the stresses or shocks they come across (Arup, 2014). However despite the growing numbers of poor and vulnerable urban inhabitants, especially those active in the informal economy, there is limited evidence of a connection between resilience efforts and informality. This is despite the fact that the informal economy is a vital factor to be considered if sustainable urban resilience and adaptation is to be achieved. It is becoming increasingly obvious that a comprehensive understanding of the informal economy should underlie any successful attempt to achieve more climate resilient economies, particularly if such attempts are to be inclusive, and to benefit the economically marginalised and insecure (Brown et al., 2009).

This paper, through a case study of Lagos, examines the significance of the presence and management of widespread informal economic activities, specifically street trade, on urban resilience and adaptation in a sprawling African megacity. Through the lens of the urban governance literature, the paper finds that the entrenched marginalisation of street traders deepens their potential susceptibility to hazards and therefore hinders any effort towards the attainment of urban resilience and adaptation in the city. It is therefore recommended that in order to advance resilience and adaptation efforts in Lagos and similar contexts, the adoption of more participatory and inclusive forms of urban governance be enshrined so that marginalised sections of society are carried along and their extensive vulnerabilities duly addressed.

\section{URBAN INFORMALITY AND RESILIENCE}

Urbanisation is a major phenomenon in the world today and is growing in significance. Between 1950 and 1975 population growth was basically equally shared between urban and rural areas globally, but in recent times urban growth has significantly taken precedence. Consequently in 2008 it was official that for the first time in history majority of the world's population now live in urban areas, and in subsequent years $90 \%$ of total new global population increase will be in cities (UNFPA 2007; Watson, 2007; McGranahan and Satterthwaite, 2014). Generally developed regions were the first to rapidly urbanise and achieve high urban shares, whilst less developed regions are only just undergoing similar processes. Urbanisation slows down as a higher ratio of people dwell in urban areas. Regions such as Europe and North America have low urbanisation rates, as over 70 percent of their population reside in urban areas, whilst rates are rising in less developed regions, with urbanisation rates estimated to be fastest in Asia with a rate of 1.4 per cent per year, followed by sub-Saharan Africa with a rate of 1.3 per cent (McGranahan and Satterthwaite, 2014).

Furthermore/consequently urban areas in the developed world are considerably well organised, and they display limited levels of inequality, which is not the case in many cities in the developing world. A key reason why urban areas in developed regions and some other areas of the world display a high level of organisation is because they developed under positive economic conditions (key being the industrial revolution), therefore urbanisation took place in line with economic development and as such there was significant prosperity which facilitated better organisation. This is not the case in many developing regions, especially sub-Saharan Africa, where urbanisation is largely characterised by considerable levels of poverty. This urban transition is creating a unique set of challenges for all concerned. As the regions with the fastest rates of urbanisation are in the developing world, which are the least prepared and unable to cope with such a challenge, thus resulting in the rapid growth of informal activities (Watson, 2007).

Urban informality and urban resilience are fundamentally linked, as both relate to the susceptibility of city inhabitants to vulnerabilities. Urban informality is generally associated with ... substantial exposure to environmental hazards, especially in developing countries where most of the urban poor depend on informal economic activities which are generally insecure, unreliable and very vulnerable to climatic and non-climatic threats (Sanderson, 2000; Mitlin and Satterthwaite, 2013; Brown et al., 2014). It is therefore argued that in order to successfully achieve urban resilience the informal economy needs to be duly considered. The resilience agenda requires significant engagement with issues of urban livelihoods. The successful transition to a more inclusive and resilient economy is dependent on the active, coordinated and careful involvement of workers in the informal economy (Brown et al., 2014). 
However Brown et. al., (2014) explain that neoliberal urban governance often worsens the exclusion experienced by the working poor as they are largely not involved in decision making and possess limited ability to influence policy. Often grassroot organisations are weak or lacking or have been co-opted by more powerful interests, especially in many developing countries which lack strong and accountable local governments. Furthermore, they argue that in order to build urban resilience and respond to environmental challenges it is important for organisations of the urban poor to be given more power, with the role of local communities in building resilience that is widely recognised.

\section{STREET TRADE AND PUBLIC SPACE}

Informal economic activities are a dominant feature of most cities in the developing world. Evidence of this is the abundance of street traders in many cities, notably in Africa where informal commerce is the main source of jobs for the growing urban poor (Brown et. al., 2009). Nevertheless street traders are continuously displaced from public spaces by city authorities, despite widespread arguments that this results in widespread social exclusion (Swanson, 2007; Lyons and Msoka, 2010; Carrieri and Murta, 2011). Street trader displacements and their impacts on traders, trading activities, and wider society vary in nature and scale. Displacements fall within a continuum between sporadic event-driven evictions to large-scale, sustained evictions (Skinner, 2008; Brown et. al., 2014).

Displacements are sometimes to alternative sites, however, they are rarely successful, with the dominant opinion in academic discourse being that trader displacements to alternative purpose built sites are generally ineffective as they not only fail to rid public spaces of traders but they also worsen the condition of traders. Substantial evidence shows that trader displacements from central locations to elaborate market developments rarely work, as displaced traders fail to attract adequate patronage to sustain their livelihood. Many researchers argue that low-value items sold from elaborate market developments typically attract insufficient clientele, and understandably street traders generally seek to avoid displacement (Lyons and Msoka, 2010; Bromley and Mackie, 2009; Mackie et al. 2014). The presence of street trading activities in public space is fundamentally contentious, with the experiences of street traders generally negative as they are typically displaced in favour of other interests.

\section{PARTICIPATION IN URBAN GOVERNANCE AND STREET TRADER MANAGEMENT IN AFRICA}

Urban governance is a popular concept which has been employed with varying connotations; however key commonalities exist across board. Governance essentially pertains to the exercise of power and despite its widespread appeal key principles underlie all discussions on governance (Devas, 2004; Lindell, 2008). The concept of governance is fundamentally linked with that of government, as both concepts essentially relate to the exercise of power. In terms of intended outputs government and governance are quite similar, government comprises of the hierarchy of decisionmaking powers within the state and the underlying institutional framework, whilst governance basically pertains to the creation of conditions for organised rule and public action, with the key difference between both being the processes that underlie both concepts (Stoker, 1998; Blakeley, 2005). The difference between both concepts has however become more defined overtime. It was previously held that governments possessed the authority and capability to effectively govern and execute their policies and plans. However, the increasing tendency towards governance discredits this perspective, as it highlights that results are based on relations between various actors, because power rather than being a state monopoly is fragmented. As such the success of plans and policies is dependent on the extent of consensus and collaboration (Devas, 2004).

The struggle for influence in the urban arena involves several stakeholders. Urban governance entails the involvement and relations between a vast array of actors and institutions, such as corporate and informal business enterprises, civil society organisations, various national, regional, and local government agencies, as well as traditional authorities (Devas, 2004). However, despite the significant opportunities for participation which urban governance presents some urban actors remain excluded, a notable example is street traders. The recent emphasis on governance has broadened the scope for groups of disadvantaged inhabitants to participate in urban decision-making, nevertheless evidence indicates that many remain excluded (Taylor, 2007), with street traders continually subject to widespread hostility and a staggering amount of violent evictions (Brown et. al., 2009). A key vehicle through which urban groups participate in urban governance is through associations, however for street traders and informal economy workers the space and opportunity to associate is particularly acute. Brown et. al. 
(2009) explain that although the avenues through which street traders influence urban policy depend on the cultural and historical context, there is a general lack of effective legal frameworks aimed at the inclusion of informal workers. There is no consistent attempt by government authorities to ensure their involvement in urban management in spite of their role as an important part of the urban workforce, with street traders continuously perceived as being illegal and trespassing on spaces meant for other uses.

The functioning of the state is critical in urban governance, especially as it concerns poor and marginal groups. Devas (2004) explains that the structure and operations of urban governance have significant impacts on urban poverty, as political processes could potentially include or exclude the urban poor, with a crucial factor being the way in which political forces play out in different situations. He, however, argues that there is no ideal model of urban governance, with the particular context and adequately defined avenues for representation and accountability being key underlying factors. Irrespective of available governance structures more powerful groups and interests are capable of influencing processes in their favour, thus relegating the poor. Therefore, what is vital is that the existing structure in a particular local context provides the maximum opportunity for the poor to have a say, make claims and enjoy basic services as a right.

The capacity of the state in urban governance has been questioned especially in the African context. The capacity of local governments in Africa to fullfill its responsibilities, such as the delivery of basic services, and policy design and implementation is often considerably limited (Devas, 1999; 2001). However Lindell (2008) argues that despite their limitations, the local state in African cities exert considerable influence in urban management, with a notable example being the widespread attacks, evictions and harassment of street traders executed by local authorities. In some contexts government authorities have made considerable progress in enhancing space for representation for communal groups in the process of urban management, however significant lapses still exist. Evidence shows a growing occurrence of orchestrated types of 'public participation' in which community associations and social networks are exploited by local governments in an autocratic manner for the provision of local services (Beall, 2001; Mitlin, 2004; Blakeley, 2005). Furthermore, in situations of decentralised governance the local government instead of being a neutral arbitrator amongst various interests seemingly selects which non-state actors to undermine and which to collaborate with (Lindell, 2008).
Stakeholder participation constitutes a vital aspect of urban governance. However participation does not always occur, and even in many situations where participation takes place it is often limited, as is generally the case with marginal groups such as street traders. This is particularly pronounced in sub-Saharan Africa where a number of structural inadequacies have combined to restrict space for civic engagement and alienate large sections of society from decision making processes as elites groups dominate urban affairs to the detriment of other segments of society. As a result, considerable sections of society remain marginal and unable to influence decision making processes, a notable case being that of street traders who remain largely helpless and unable to get their voices heard in the face of decisions which largely favour elite interests as is typically the case in the process of street trader displacements.

\section{THE LAGOS CASE STUDY}

This paper is based on the investigation into the informal economy in Lagos, Nigeria. Lagos is an ideal setting in which to generate new insights into urban governance and the workings of the informal economy. Lagos with a population of about seventeen million people is the largest city as well as the economic hub of Nigeria, the most populous country in Africa. Politically Nigeria has a mixed history, but in recent times it has managed a reasonable level of political stability. Since its independence from the British in 1960, it has experienced a civil war, several military coups and was virtually under continuous military rule up until 1999 when a civilian government was elected (Istrate, 2007). From 1999 to date it has been under democratic rule, but despite relative political stability and undoubted economic potential, it remains an under-developed country with high levels of inequality. Nigeria also boasts to be the largest economy in Africa as well as the largest and most dynamic informal economy on the continent (Skinner, 2008; Meagher, 2010).

Lagos also possesses a huge and deeply entrenched informal economy (Omoegun, 2015). It is estimated that about 50$75 \%$ of the workforce of Lagos is employed informally (LSG, 2004; 2013). The informal economy in Lagos therefore provides livelihoods for millions of people, notably in street trading, and this understandably poses significant management challenges. The case study was conducted through mixed-methods approach comprising of interviews, documentary analysis and observation, including a questionnaire survey of hundred street traders, semi-structured interviews with some selected key informants including government officials (local and state) and members of civil society in Lagos. 


\section{Participation in Urban and Public Space Management in Lagos}

In the light of the challenges associated with urban governance in Africa, especially the challenges which marginal groups face in participating in urban governance as earlier discussed, this section explores the extent of stakeholder involvement in urban management in Lagos, with a focus on the nature of relations between government authorities (state and local) and street traders and their associations.

\section{Tokenistic and Selective Engagement in Urban Management}

Following the transition from military to civilian rule in Nigeria in 1999, the Lagos State Government (LSG) tried to move away from authoritarian urban management and promote improved stakeholder participation in urban planning as highlighted by two senior officials of the Lagos State Ministry of Physical Planning and Urban Development:

" This government especially has been trying so much ... there is this planning approach ... you don't plan for the people, you plan with the people, so over time there are consultations and stakeholder meetings ..." (LSG Official, Ministry of Physical Planning and Urban Development, KI 8).

"...we plan with the people not just for them, we allow them to buy into the plans and developments government is undertaking" (LSG Official, Ministry of Physical Planning and Urban Development, KI 3 ).

However there is a clear lop-sidedness in the implementation of the participatory approach, especially with regards to street trading. As clear from the interviews with officials of the LSG, the participation exercises with stakeholders are referred to as merely consultations and are not in-depth, with the aim of giving credibility to decisions already taken:

"What we do ... is ... persuasive compliance when these laws are made or the rules and regulations ... we do some stakeholders meetings, we get them involved $\ldots$ and we ensure that we let them see the need for compliance ..." (LSG Official, Ministry of Physical Planning and Urban Development, KI 3).

The seeming irregularities in the claimed participatory approach to urban planning by the LSG raises questions about the nature of trader's participation in the process. Therefore, the interactions between government authorities (state and local) and street traders in the process of urban management are discussed in the next section.

\section{Disconnect Between Policy Makers and Traders}

The relationship between government authorities and street traders is rather detached, which is considerably due to the authoritarian antecedents and intolerant attitude of government authorities towards street trade. For traders their unfavourable past experiences with government authorities and the generally negative and repressive attitudes of authorities towards their activities hinder their interaction with policy makers. As one of the traders said:

“... we don't know where the government is, we cannot get near them ..." (Female trader [22], Adekoya Street, selling raw food items, [Displaced]).

“... we know government can do anything, even where we are we know they can destroy the shop when they like ... it is where government push us that we will stay" (Female trader [25], Idera Formal Market, selling Poultry, [Displaced]).

At both the local and state government levels there is a clear disconnect with street traders and little knowledge of the number of street traders or the nature of their activities is indicated by many of the government respondents in the interview data. This lack of knowledge about street trading is vividly described by a state government official.

“... we don't know who is doing what, and what the population of people out there is ... that is why the government is now trying to find a way of capturing them by enumerating them and then organising them into associations that will be easier to manage ..." (LSG Official, Ministry of Commerce and Industry, KI $6)$.

In terms of priorities regarding the persistence of street trading activities, the disconnect between policy makers and traders is also apparent, while understandably the focus of traders is on the maintenance of their livelihoods, the attention of government authorities centres around issues of revenue generation and environmental cleansing.

"Government recognizes ... the extent of the informal economy ... but they are unaware of ... the dynamics .... What government often times is concerned about is how to collect some form of taxes and compensation ..." (LSG Official, Ministry of Commerce and Industry, KI 5).

This clear difference in priorities, particularly in the light of the intolerant attitude of government authorities towards street trade, has left many traders frustrated, with an air of 
resentment towards government authorities.

"It's what happens in the country, we follow, it's what powerful people do, we follow ... normally the government is meant to work for the people's progress but it is not so here ... the government is not interested ... maybe in the future God can give us a government that is willing to help ... government is doing things for selfish gains and not in the interest of the majority ..." (Male trader [52], Ariyibi Oke Street, selling meat, [Displaced]).

\section{Fragmented Trader Voices}

Street traders in Lagos have a very limited propensity to form collective associations. Many informal economy workers in Lagos do have associations and umbrella associations, but there are none for street traders (Interview with Secretary General of Federation of Informal Workers of Nigeria, KI 15). Government authorities argue that they consult with market associations, but market-trader associations mainly represent formal traders or productbased trader associations. Some street traders are members of both market-trader and product associations, but neither prioritise issues faced by street traders, most of whom operate informally without trading licenses or rights to a trading space. Most street traders are not involved in the choice of the leaders of these associations, especially those of formal market- trader associations:

“...we have leaders here; Babaloja (Mala Head of Market Trader Asociation) and Iyaloja (Female Head of Market Trader Association) but I don't know how people become Babaloja and Iyaloja ... I don't understand" (Male trader [5], Olorunshogo Formal Market, selling raw food items, [Displaced]).

“... we have Iyaloja and Babaloja who are appointed by the government, we are not involved in choosing them" (Female trader [7], Banjoko Street, selling clothing, [Not displaced]).

“...communication [from government regarding our occupation] is with head of market (Iyaloja) and government appoints the Iyaloja" (Female trader [2], Macarthy Lane, selling cosmetics, [Not displaced]).

The leaders of these associations are mainly the ones in contact with government authorities and are meant to represent the interest of members, however there are indications that this is not the case, especially when it comes to the activities of street traders. Suggestions of corruption and compromise have been levelled against these leaders, and a significant level of government involvement has been identified in their activities. A number of other studies have also identified the existence of such clientelist links between trader associations and political parties (Bhowmik, 2005; Crossa, 2009; Njaya, 2014). Market leaders in Lagos have increasingly become politicised, having demonstrated a high level of support for the dominant political party in Lagos and the previous Governor. A trader vividly makes reference to the compromised status of market-trader associations leaders in her comment:

"... [We have been consulted by government authorities on issues regarding our occupation] just once as far as I know, [the government] don't call us, only the Iyaloja or Babaloja do, in this country money has spoilt everything, people that will tell the truth do not have access ... only God can [help us get our voices heard], there are Iyaloja and Babaloja so the government won't listen to you" (Female trader [8], Macarthy Lane, selling clothes, [Not displaced]).

It is clear from the foregoing that the nature of engagement between government authorities and street traders in urban management in Lagos is poor, with traders having limited influence in urban management and their collective voice significantly hindered. As a result street traders are largely unable to influence decision making processes and are generally subject to the often repressive government policies typified by regular street trader displacements. The consequences of displacements include a worsening of the already precarious working conditions of street traders, both with regards to the locations they occupy as well as the overall conduct of their activities. Thus, the poor level of engagement between government authorities and street traders constitutes a major hindrance to urban resilience and adaptation efforts, particularly due to the immense scale of street trading activities in urban areas.

\section{CONCLUSION}

This article highlights the challenges of achieving urban resilience and adaptation in the presence of widespread street trade in Lagos, Nigeria, especially in the light of the limitations traders experience in participating in urban governance and public space management. This section summarises the major issues identified and the key findings of the study. The extent of stakeholder participation in the process of urban governance in Lagos is explored, with a focus on the nature of engagement between government authorities and street traders. 
A major finding was the limited involvement of traders in urban and public space management, which is mainly the result of unique political history of Nigeria and Lagos, which consists of significant periods of colonial and military rule, which have had a lasting impact on urban affairs. This political history is a major contributory factor to the authoritarian approach to urban planning in Lagos and is a fundamental reason behind the failings in urban governance, which combined have led to the regular displacement of street traders from public spaces, mainly motivated by the state government.

The limited involvement of traders in urban management in Lagos is further exacerbated by the recent uptake of neoliberal ideals by the state government, which has worsened previously held prejudices against informal activities, particularly street trade, and intensified efforts aimed at displacing street traders from central public spaces to the benefit of elite interests. The restricted involvement of street traders in urban management has been highlighted by some other studies (Crossa, 2012; Mackie et al. 2014). Nevertheless, in these studies it was observed that street traders in Mexico and Cusco managed to influence urban management to some extent, in contrast to Lagos where traders were incapable of doing the same, mainly as a result of the unique political antecedent of Lagos. Furthermore, a clear disconnect between policy makers and traders was identified, with a major issue being the restricted ability of street traders to participate in urban decision-making processes. It was found that the restricted influence of street traders in urban management was particularly a result of weak association membership amongst street traders, which is significantly an outcome of the regular street trader displacements in Lagos and Nigeria.
Furthermore, a conspicuous lack of an umbrella association solely for street traders in Lagos or Nigeria was identified, in spite of the availability of such associations for other informal workers.

From the evidence in Lagos it is clear that large sections of the urban populace are restricted from participation in urban governance and marginalised in urban affairs, most notably (often poor) street traders who constitute a significant section of the huge informal economy in the city. As a result, urban resilience and adaptation efforts in Lagos and similar contexts is significantly hindered, as the daily survival and prosperity of this key segment of the population and crucially their survival in the face of potential hazards is paramount in urban resilience and adaptation. However, considering that the marginalisation of this key population in urban affairs, as evidenced by regular displacements, clearly hinders their survival under normal circumstances, with their situation significantly worsened in the occurrence of any hazards, it is imperative that in line with efforts at achieving urban resilience, simultaneous efforts at improving urban governance should be sought. This would be through the active engagement with associations of informal economy workers and related associations or the urban poor, in order to better understand their challenges and ensure they are better integrated into the urban society. This will enhance their resilience and adaptability potentials and consequently the overall urban resilience and adaptability. It is therefore imperative that efforts at achieving urban resilience and adaptability in Lagos and similar contexts be woven around strategies towards the attainment of inclusive urban governance and participatory planning in order to be

\section{REFERENCES}

Arup, 2014, City Resilience Framework, viewed 2 February 2017, from https://assets.rockefellerfoundation.org/app/uploads/20140410162455/City-Resilience-Framework-2015.pdf

Beall, J., 2001, "Valuing Social Resources or Capitalising on Them? Limits to Pro-poor Urban Governance in Nine Cities of the South", International Planning Studies 6(4), 357-375.

Bhowmik, S., 2005, "Street Vendors in Asia: A Review", Economic and Political Weekly May 28-June 4, $2256-2264$.

Blakeley, G., 2005, “Local Governance and Local Democracy: The Barcelona Model”, Local Government Studies (31), 149-165.

Bromley, R. D. F., and Mackie, P., 2009, "Displacement and the New Spaces for Informal Trade in the Latin American City Centre", Urban Studies 46(7), 1485-1506.

Brown, A. Lyons, M., and Dankoco, I., 2009, "Street Traders and the Emerging Spaces for Urban Voice and Citizenship in African Cities", Urban Studies, 47(3), 1-18. 
Brown, A. Msoka, C., and Dankoco, I., 2014, "A refugee in my own country: Evictions or property rights in the urban informal economy?”, Urban Studies, 52(12) 2234-2249.

Carrieri, A. and Murta, I., 2011, "Cleaning up the City: A study on the removal of street vendors from down town Belo Horizonte, Brazil”, Canadian Journal of Administrative Sciences, 28(2), 217-225.

Crossa, V., 2009, “Resisting the Entrepreneurial City: Street Vendors' Struggle in Mexico City’s Historic Centre”, International Journal of Urban and Regional Research, 33(1), 43-63.

Crossa, V., 2012, "Disruption, yet Community Reconstitution: Subverting the Privatization of Latin American Plazas", GeoJournal 77(2), 167-183.

Devas, N., 1999, Who Runs Cities? The Relationship between Urban Governance, Service Delivery and Poverty. Urban Governance, Poverty and Partnerships Working Paper, No 4. Birmingham: University of Birmingham.

Devas, N., 2001, “Does City Governance Matter for the Urban Poor?”, International Planning Studies, 6(4), $393-408$.

Devas, N., 2004, "Urban Poverty and Governance in an Era of Globalization, Decentralization and Democratization", In: Devas, N., Urban Governance, Voice and Poverty in the Developing World. London. Earthscan, 15-36.

Istrate, E., 2007, "Entrepreneurs versus Survivalists in the Urban Informal Economy: An approach based on firm size", Paper prepared for the Entrepreneurship, Institutions, and Policies: The 2007 Ratio Colloquium for Young Social Scientists. Stockholm, 1-28.

Lagos State Government/UN-Habitat Office in Nigeria, 2004 (LSG), State of the Lagos Mega City and Other Nigerian Cities Report.

Lagos State Government (LSG), 2013, Lagos State Development Plan 2012-2025, Lagos: Ministry of Economic Planning and Budget.

Lindell, I., 2008, “The Multiple Sites of Urban Governance: Insights from an African City”, Urban Studies, 45(9), 1879-1901.

Lyons, M. and Msoka, C., 2010, “The World Bank and the Street: (How) Do 'Doing Business' Reforms Affect Tanzania's Micro-traders?”, Urban Studies, 47(5), 1079-1097.

Mackie, P. Bromley, R. D. F. and Brown, A., 2014, "Informal traders and the battlegrounds of revanchism in Cusco, Peru", International Journal of Urban and Regional Research 38(5), 1884-1903.

McGranahan, G. and Satterthwaite, D., 2014, Urbanisation Concepts and Trends, IIED, London.

Meagher, K., 2010, Identity Economics: Social Networks and the Informal Economy in Nigeria, Cambridge: Cambridge University Press.

Mitlin, D. and Satterthwaite, D., 2013, Urban Poverty in the Global South: Scale and Nature, Routledge, London.

Mitlin, D., 2004, “Civil Society Organizations: Do They Make a Difference to Urban Poverty?”, In: Devas, N., Urban Governance, Voice and Poverty in the Developing World. London. Earthscan, 123-144.

Njaya, T., 2014, "Challenges of Negotiating Sectoral Governance of Street Vending Sector in Harare Metropolitan, Zimbabwe", Asian Journal of Economic Modelling 2(2), 69-84.

Omoegun, A., 2015, Street Trader Displacements and the Relevance of the Right to the City Concept in a Rapidly Urbanising African City: Lagos, Nigeria. PhD Thesis, Cardiff University.

Sanderson, D., 2000, "Cities, disasters and livelihoods", Environment and Urbanization, 12(2), 93-102.

Skinner, C., 2008, Street Trade in Africa: A review, Women in Informal Employment Globalizing and Organising (WEIGO) Working paper, No 5. Cambridge: WEIGO.

Stoker, G., 1998, “Governance as Theory: Five Propositions”, International Social Science Journal 50 (155), 17-28. 
Swanson, K., 2007, "Revanchist Urbanism Heads South: The Regulation of Indigenous Beggars and Street Vendors in Ecuador", Antipode, 39(4), 708-728.

Taylor, M., 2007, "Community Participation in the Real World: Opportunities and Pitfalls in New Governance", Urban Studies, 44(2), 297-317.

UNFPA, 2007, State of the world population 2007: unleashing the potential of urban growth, New York: United Nations Population Fund.

Watson, V., 2007, 'Urban Planning and Twenty-First Century Cities: Can it Meet the Challenge' in Global Urban Poverty: Setting the Agenda (edited by Garland, A., Massoumi, M. and Ruble, B.), Woodrow Wilson International Centre for Scholars, Washinton, D.C. 